\title{
R19 - DESENVOLVIMENTO E VALIDAÇÃO DE TESTE DE QUANTIFICAÇÃO DE CARGA VIRAL DE HCV DE BIO-MANGUINHOS
}

\author{
Elisabete Andrade ${ }^{1}$; Daniele Rocha ${ }^{1}$; Marcela Fontana ${ }^{1}$; Marcelo Corrêa; William Pires; \\ Antonio G. P. Ferreira ${ }^{1}$; Patrícia Alvarez ${ }^{1}$ \\ ${ }^{1}$ LATED/VDTEC/Bio-Manguinhos/Fiocruz; \\ ${ }^{2}$ SEDES/VGEST/Bio-Manguinhos/Fiocruz;
}

Objetivo: Desenvolver e validar um teste molecular destinado à quantificação dos genótipos 1 a 6 do Vírus de Hepatite C (HCV). A quantificação da carga viral (QCV) do HCV circulante em plasma humano representa uma ferramenta importante para o prognóstico e acompanhamento clínico do paciente portador de $\mathrm{HCV}$, auxiliando na administração, duração e monitoramento da terapia antiviral. Os ensaios comerciais destinados à quantificação de carga viral de HCV, no Brasil, são comercializados com custos abusivos e a obtenção de uma alternativa nacional possibilitará ampliar significativamente o acesso da população.

Metodologia: O teste de QCV em ensaio duplex para HCV (fluorescência FAM) e Calibrador Interno (fluorescência Dye3) tem como base a plataforma de PCR em tempo real utilizando uma curva padrão obtida com um VLP (virus like partical) que contem a inserção de parte do genoma do HCV (derivado de uma Patente da FIOCRUZ). Para a validação do teste foi realizada comparação com um kit comercial, COBAS Taqman HCV Test (v2.0), analisando-se precisão e exatidão entre os testes preconizados pela RDC n 27/2012 (ANVISA). Para a validação foi utilizada o coeficiente de variação (CV) não se admitindo valores superiores a 15\%, exceto para o limite inferior de detecção, admitindo-se valores menores ou iguais a $20 \%$. Foram processadas amostras HCV positivas e painéis internacionais de quantificação, além de interferentes.

Resultado: A QCV de HCV foi estabelecida utilizando-se um curva padrão de quantificação com 3 pontos com diferentes concentrações, obtida ao longo de um exaustivo processo de padronização. O cálculo da QCV é realizado, por intermédio de software desenvolvido pela equipe de TI de Bio-Manguinhos, comparando-se o CT 
encontrado da amostra, com os CTs dos 3 pontos da curva padrão, gerando um resultado em UI/mL e Log. O limite de quantificação deste teste de QCV de HCV é de 2,0E+06 a $6,0 \mathrm{E}+01 \mathrm{IU} / \mathrm{mL}$ e o limite inferior de detecção é de 3,0E+01IU $/ \mathrm{mL}$. Na validação os valores encontrados de CV ficaram dentro da faixa estabelecida na RDC $n^{\circ} 27$. A diferença máxima de log encontrada entre o teste desenvolvido em Bio-Manguinhos e o comercial foi de $0,7 \log$ na carga viral de $6,0 \mathrm{E}+01 \mathrm{UI} / \mathrm{mL}$ e a média de variação foi inferior a $0,4 \log$.

Conclusão: Os resultados da validação mostraram que o teste de QCV de HCV desenvolvido em Bio-Manguinhos está dentro dos padrões estabelecidos na RDC $\mathrm{n}^{\circ}$ 27/2012. A diferença de log encontrada entre o teste desenvolvido e o comercial para a carga viral de 6,0E+01UI/mL está diretamente relacionada à maior variação na faixa do limite de sensibilidade dos testes, não sendo relevante clinicamente. Com relação à reprodutibilidade entre replicatas de amostras, a metodologia de Bio-Manguinhos apresentou resultados mais robustos com menor nível de variação se comparado ao Kit comercial. 